17. Ситковская О. Д. Психологический комментарий к отдельным статьям Уголовного кодекса Российской Федерации (части Общая и Особенная). Москва: Акад. Генеральной прокуратуры Российской Федерации, 2009. 180 с.

18. Семке В. Я. Истерические состояния. Москва: Медицина, 1988. 224 с.

19. Шевченко А. Є., Соловйова В. В., Стрельник О. Л. Обставини, що виключають юридичну відповідальність: монографія. Донецьк: Юго-Восток, 2011. 177 с.

20. Беляев Н. А. Курс советского уголовного права. Часть Общая / отв. ред. Н. А. Беляев, М. Д. Шаргородский. Том 1. Л.: Изд-во ЛГУ, 1970. 868 с.

DOI 10.31558/2518-7953.2019.1.12

УДК 343.131

\author{
I. А. Щербак \\ доцент кафедри конституційного, \\ міжнародного і кримінального права \\ Донецького національного університету \\ імені Василя Стуса, \\ канд. юрид. наук, доцент
}

\title{
ПРОБЛЕМНІ АСПЕКТИ ПРОЦЕДУРИ ПОВІДОМЛЕННЯ ПРО ПІДОЗРУ В КОНТЕКСТІ РЕАЛІЗАЦІЇ ПРИНЦИПУ ВЕРХОВЕНСТВА ПРАВА
}

Ключові слова: кримінальне провадження, повідомлення про підозру, принции верховенства права, права і свободи людини, окремі категорії осіб.

Згідно зі ст. 8 Кримінального процесуального кодексу України (далі - КПК України) кримінальне провадження здійснюється з додержанням принципу верховенства права, відповідно до якого людина, її права та свободи визнаються найвищими цінностями та визначають зміст і спрямованість діяльності держави.

Складність і багатогранність категорії верховенства права значно ускладнює будь-яку спробу сформулювати універсальне визначення цього поняття, прийнятне для усіх галузей права, для усіх життєвих ситуацій [1, с. 7]. Однак, потрібно погодитись 3 провідними спеціалістами цієї сфери в тому, що зазначений принцип є базовим, адже він визначає умови та спосіб побудови і діяльності правової системи взагалі, а також її окремих складових - галузей права, у тому числі й кримінально-процесуального права [2, с. 516].

Зміст верховенства права науковцями традиційно зводиться до двох основних концепцій: «формальної» та «матеріальної» (змістовної) [3, с. 162-169]. Формальний аспект полягає у тому, що в суспільстві мають існувати правові норми, яких дотримуються всі суб'єкти, у тому числі й держава. Норми мають бути зрозумілими, чіткими, ясними і несуперечливими, доступними, і зазвичай не мати 
зворотної дії у часі, розумно стабільними, а правотворчість послідовною, і має існувати усталена практика реалізації норм права, що підтримується гарантією їх однакового застосування. Матеріальний аспект верховенства права полягає у тому, що мають існувати доволі чіткі змістовні стандарти, які визначають сутність позитивного права. Основною вимогою цього аспекту є те, що норми права мають відповідати стандартам основоположних прав і свобод людини та громадянина, а також загальним засадам права і іншим принципам природного права [3, с. 167].

У кримінальному провадженні принцип верховенства права застосовується з урахуванням практики Свропейського суду з прав людини, який діє на основі Конвенції про захист прав людини і основоположних свобод 1950 року (далі Конвенція), що стала частиною національного законодавства. Основоположні, загальновизнані міжнародні (зокрема, європейські) стандарти та принципи у галузі прав людини - це визнані більшістю держав, що широко представляють різні соціально-економічні системи та континенти, обов'язкові правила поведінки у сфері забезпечення прав, свобод та законних інтересів, які закріплюють досягнутий рівень розвитку світової спільноти у встановленні правового статусу людини і громадянина, зокрема у кримінальному процесі [4, с. 101]. Принцип верховенства права з позицій кримінально-процесуального права змістовно охоплює процесуальні права із правами людини. Оскільки цей принцип належить до загальновизнаних принципів, варто підкреслити важливість його дотримання усіма органами влади.

Протягом тривалого часу в національній правовій системі імплементація норм зазначеної Конвенції та застосування практики Європейського суду з прав людини (далі - ССПЛ) при здійсненні правосуддя впроваджувалися повільно, що зумовило непоодинокі порушення прав людини і як наслідок - значну кількість звернень до ЄСПЛ громадян України. Це по-суті вказувало на порушення у реалізації загальновизнаного принципу верховенства права. Ступінь впровадження цього принципу в державі впливає на прийняття справедливих законів та правильність їх застосування.

Питання кримінально-процесуальної регламентації повідомлення про підозру достатньо змістовно висвітлені у роботах Ю. П. Аленіна, І. В. Гловюк, Д. Д. Нікіфорова, І. Г. Івасюк, М. А. Погорецького, А. Р. Туманянца, О. Ю. Татарова, В. А. Шкелебей, О. Фараон та багатьох інших науковців та практиків. Принцип верховенства права, його сутність та значення в різні часи досліджували багато представників різних галузей юридичної науки, зокрема, й в контексті засад кримінального процесуального права (В. Г. Гончаренко, Ю. М. Грошевий, Т. М. Добровольська, М. І. Козюбра, О. П. Кучинська, О. М. Ларін, Л. М. Лобойко, В. Т. Маляренко, М. М. Михеєнко, О.Р.Михайленко, В.В.Навроцька, В.В.Назаров, В. В. Рожнова, А. А. Стрижак, В. М. Тертишник, В. П. Шибіко, М.С. Шумило та 
ін.). Втім, на етапі реформування кримінального судочинства особливої актуальності для європейської держави набуває правозастосовчий аспект дотримання принципу верховенства права. Адже зміст та форма оновленого кримінального провадження повинні відповідати принципу верховенства права на всіх стадіях кримінального процесу, у тому числі при здійсненні процедури повідомлення про підозру.

Метою циієї статті є обтрунтування пропозичій щодо уточнення прочедури повідомлення про підозру з урахуванням реалізаиії принципу верховенства права.

Прийняття в 2012 році нового КПК України наблизило нашу країну до європейських стандартів кримінального процесу, адже вперше в окремій главі КПК України було закріплено засади кримінального провадження - визначальні, фундаментальні, імперативні положення щодо закономірностей і найбільш суттєвих властивостей кримінального процесу, які обумовлюють їх значення як засобу для захисту прав і свобод людини і громадянина, а також регулюють діяльність органів та посадових осіб, які ведуть кримінальне провадження. Серед таких засад визначено верховенство права, яке $є$ як й інші принципи керівним положенням для закріплення завдань кримінального провадження, побудови його стадій, окремих проваджень, інститутів [5, с. 16-17].

Гарантією реалізації принципу верховенства права $є$ закріплення в КПК України чітких правил і процедур здійснення кримінального провадження. Pеалізація принципу верховенства права як основоположної, визначальної позиції для суб'єкта правозастосування повинна бути забезпечена дієвими механізмами, встановленими законом. Однак, при формальному закріпленні чітких правил у чинному КПК України правозастосовча їх практика свідчить про існуючі сьогодні складнощі реалізації принципу верховенства права у кримінальному судочинстві, особливо на етапі досудового розслідування. Зокрема, варто звернути увагу на окремі проблемні аспекти реалізації цього принципу на стадії досудового розслідування під час повідомлення про підозру.

Вказана процедура, що здійснюється з підстав, визначених ч. 1 ст. 276 КПК України, призводить часто не тільки до протизаконного та безпідставного обмеження прав учасників кримінального провадження, а й у подальшому ставить під сумнів можливість досягнення завдань кримінального провадження у цілому. Стаття 2 КПК України, визначаючи завдання кримінального провадження, встановлює напрям кримінально-процесуальної діяльності. Одним з цих завдань є забезпечення швидкого, повного та неупередженого розслідування і судового розгляду $з$ тим, щоб до кожного учасника кримінального провадження була застосована належна правова процедура.

В КПК України загальна процедура повідомлення про підозру регулюється главою 22 (статті 276-279), а процедура здійснення повідомлення про підозру окремим категоріям осіб встановлена главою 37 (статті 480-483). 
Поняття «повідомлення про підозру у вчиненні кримінального правопорушення» у КПК України вживається у двох значеннях: а) для позначення відповідного процесуального акта, складеного прокурором - процесуальним керівником або слідчим, який визначений (призначений) керівником органу досудового розслідування для здійснення досудового розслідування у кримінальному провадженні; при цьому повідомлення про підозру як процесуальний акт має містити відомості, вичерпний перелік яких наведено у ст. 277 КПК; б) для позначення відповідної процесуальної дії стосовно складення та вручення повідомлення особі про підозру у вчиненні нею кримінального правопорушення.

Слід зазначити, що передбачені кодексом наслідки тягне як факт складання повідомлення про підозру у вчиненні кримінального правопорушення - процесуального документа, так і факт вчинення дій щодо вручення такого документа особі у встановлений законом строк та спосіб.

Нездійснення вручення особі (в тому числі особі окремої категорії) письмового повідомлення про підозру у встановлений законом строк та спосіб нівелює процесуальне значення повідомлення про підозру як процесуального документа, оскільки такий документ не здатний спричинити юридичні наслідки для учасників кримінального провадження.

Отже, окремої уваги заслуговує питання щодо суб'єктного складу осіб, які мають право складати та вручати особі у передбачений законом спосіб письмове повідомлення про підозру.

В ч. 1 ст. 278 КПК закріплено, що письмове повідомлення про підозру вручається у день його складення слідчим або прокурором, а у разі неможливості такого вручення - у спосіб, передбачений КПК України для вручення повідомлень [6]. Особі, яка не належить до окремої категорії, вручення повідомлення про підозру може здійснюватися іншим прокурором або слідчим, якому доручено здійснити таку процесуальну дію відповідно до п. 4 ч. 1 ст. 36 КПК України.

Особливого значення вказане питання набуває в аспекті здійснення повідомлення про підозру окремим категоріям осіб, визначеним статтями 480, 481 КПК України (зокрема, народним депутатам України, адвокатам, суддям, сільському, селищному, міському голові тощо). Адже у окремих випадках законодавець встановлює особливі порядки провадження - диференційовані в залежності від характеристик суб'єкта, щодо якого здійснюється кримінальне провадження, або характеристик вчиненого злочину.

Слідуючи положенням статей 276, 278, 481 КПК України процесуальні дії щодо складення та вручення повідомлення про підозру може вчинити виключно одна й та сама службова особа: слідчий або прокурор - процесуальний керівник, який у випадку повідомлення про підозру окремим категоріям осіб повинен займати певну адміністративну посаду (наприклад, Генеральний прокурор або його 
заступник). Особи, які не складали повідомлення про підозру, не мають права його вручати. Такої позиції дотримуються багато науковців і практиків [7; 8, c. $113 ; 9]$.

Однак, у статтях 277, 278, 481 КПК України використовуються в цьому сенсі стосовно письмового документа і комплексу дій (прийняття процесуального рішення, його оформлення у вигляді письмового документа, проголошення та вручення з роз'ясненням прав особи, якій проголошено підозру) різні терміни «складення», «вручення», «здійснення» повідомлення про підозру. Ця позиція законодавця призводить до неоднозначного розуміння терміну «здійснення повідомлення про підозру» та складнощів правозастосування, особливо в разі повідомлення про підозру окремим категоріям осіб.

У зв'язку з цим є підстави вважати, що стосовно осіб окремої категорії вся процедура повідомлення про підозру повинна здійснюватися однією уповноваженою службовою особою. При цьому варто враховувати, що норми стосовно порядку притягнення до кримінальної відповідальності окремих категорій осіб містяться й у законах («Про судоустрій і статус суддів», «Про адвокатуру та адвокатську діяльність»), які є спеціальними щодо КПК України стосовно здійснення повідомлення про підозру. Наприклад, в ч. 4 ст. 49 Закону України «Про судоустрій та статус суддів» закріплено, що судді може бути повідомлено про підозру у вчиненні кримінального правопорушення лише Генеральним прокурором або його заступником [10]. Закон також вказує на здійснення спеціально уповноваженою особою більшого комплексу дій стосовно повідомлення про підозру суб'єкту зі спеціальним статусом, а не лише складання тексту письмового повідомлення (як визначено у статтях 277, 278 КПК України). Такий підхід підкреслює особливий статус осіб окремої категорії, закріплений у спеціальних законах, і реалізує гарантії їх незалежності.

Наведена позиція знайшла підтвердження, зокрема, у рішенні Апеляційного суду Полтавської області від 6 вересня 2016 р. у справі № 538/1807/15-к [11]. В ньому йдеться про особисте повідомлення про підозру, тобто обов'язкове безпосереднє вручення особі відповідного письмового процесуального акту належною службовою особою міському голові. Рішення суду першої інстанції скасовано, $\mathrm{i}$ призначено новий розгляд у суді першої інстанції в іншому складі суду. Причиною стала відсутність в матеріалах провадження підтвердження про вручення повідомлення про підозру судді, а також відсутність його підпису, який засвідчує, що він отримав це повідомлення. Відповідно до п. 1 ч. 1 ст. 481 КПК письмове повідомлення про підозру міському голові здійснюється зокрема прокурором області. В судовому рішенні зазначено: «Повноваження повідомляти будь-якій особі про підозру, зокрема й міському голові як спеціальному суб'єкту, пов'язуються 3 наявністю права процесуального керівництва досудовим розслідуван- 
ням, що є визначальним, а отже, первинним, оскільки випливає з необхідності нагляду за додержанням законів під час проведення досудового розслідування. Службова особа, яка не здійснює прокурорського нагляду в конкретному кримінальному провадженні не допущена до матеріалів провадження, а тому не в змозі дати оцінку наявності достатніх доказів та їх обгрунтованості для підозри особи у вчиненні кримінального правопорушення. Здійснення повідомлення про підозру міському голові виключно прокурором області $є$ похідним повноваженням від первинного права, що випливає 3 процесуального керівництва. Обмеження переліку процесуальних керівників у кримінальному провадженні, що мають право повідомляти про підозру міським головам, зумовлене особливим статусом останніх» [11]. Зі змісту ст. ст. 42, 277 КПК випливає, що процесуального статусу підозрюваного (крім випадку затримання) особа набуває не після складання тексту, а лише після вручення повідомлення. Саме із цим моментом пов’язується набуття особою відповідних процесуальних прав після їх роз'яснення слідчим, прокурором. Таким чином, сам факт складання письмового тексту повідомлення про підозру без його безпосереднього вручення відповідною особою не може бути розцінений як виконання нею усього комплексу дій, що охоплюються поняттям «здійснити повідомлення про підозру». Тобто здійснити весь комплекс дій стосовно міського голови зобов'язаний виключно прокурор області відповідно ч. 1 ст. 481 КПК.

Про проблеми, пов'язані з врученням повідомлення про підозру свідчить також рішення Донецького апеляційного суду у справі № 263/11808/18 від 15 березня 2019 р. Підставами для скасування повідомлення про підозру стали процесуальні порушення, пов'язані з врученням підозри, а саме, суд дійшов висновку, що повідомлення про підозру вручене до внесення даних про кримінальне правопорушення до Єдиного реєстру досудових розслідувань. Крім того, в описовій частині зазначений один слідчий, а після опису фактичних обставин міститься підпис іншого слідчого, який не складав повідомлення про підозру. Також суд звернув увагу на те, що спосіб вручення повідомлення про підозру шляхом надіслання поштою є незаконним [12].

Неоднозначність правозастосовчої практики щодо повідомлення про підозру в наведеному прикладі підтверджується ще тим, що суд першої інстанції не звернув уваги на порушення процедури повідомлення про підозру, які встановив суд апеляційної інстанції.

Наявність різних позицій щодо правозастосовчої практики у цьому питанні не відповідає практиці Свропейського суду з прав людини, який у своїх рішеннях наголошує, що процесуальні акти повинні відповідати концепції передбачуваності. Конвенція про захист прав людини та основоположних свобод відсилає 
до законодавства, вимагаючи, щоб воно було доступним для зацікавлених осіб, чітким і передбачуваним у застосуванні («Беєлер проти Італії») [13].

Вбачається, що причиною різного підходу до порядку здійснення повідомлення про підозру особі (в тому числі окремої категорії), є надання законодавцем «повідомленню про підозру» подвійного значення: як певного комплексу дій (процедури) і як окремого процесуального документа.

Для розуміння шляхів вирішення вказаних проблем стосовно процедури повідомлення про підозру необхідно звернутися до категорії «кримінально-процесуальна форма». В науці кримінального процесу ця категорія є центральною, адже вона втілює багато аспектів кримінально-процесуальної діяльності. О. В. Смирнов та К. Б. Калиновський справедливо до змісту їі включають процедури та процесуальні умови. Процедури - це послідовність, черговість здійснення тих чи інших процесуальних дій, а процесуальні умови - це нормативні приписи, які встановлюють підстави провадження процесуальних дій, різні заборони та обмеження на здійснення ряду дій, визначають коло учасників процесуальних дій та їх правовий статус, а також місце, строк чи час проведення процесуальних дій [14, c. 15-16]. Для удосконалення процедури повідомлення про підозру з метою забезпечення дотримання та захисту прав людини окремі науковці звертають увагу на потребу у деталізованому роз'ясненні поняття «вручення», «належного вручення» та «отримання» повідомлення про підозру на законодавчому рівні [8, с. 113; 15, с. 114]. При дослідженні способів вручення повідомлення про підозру О. Фараон зазначає, що «надання зазначеним у повістці положенням нормативного характеру передбачає необхідність їх дотримання під час застосування будь-якого способу здійснення виклику» [15, с. 115].

Тож, процедура повідомлення про підозру повинна бути єдиною у всіх кримінальних провадженнях, що буде відповідати принципу верховенства права у кримінальному судочинстві на його стадіях та етапах. При цьому існує окрема категорія осіб, щодо яких процесуальна форма їх повідомлення про підозру має особливості, тобто запроваджуються додаткові, порівняно із главою 22 КПК, гарантії, що надаються державою.

Таким чином, розглянуті вище на прикладах процедури повідомлення про підозру питання реалізачіï принципу верховенства права дозволяють визнати, щуо відсутність однозначного та однакового розуміння учасниками кримінального провадження прочесуальних прочедур призводить до порушення изього принцчипу, а також зумовлює потребу подальшого нормотворчого прочесу у цій галузі права.

Існує необхідність уточнення процедури «здійснення повідомлення про підозру» щуодо окремих категорій осіб иляхом внесення відповідних змін до глави 37 КПК України. Задля реалізації принцииу верховенства права у кримінальному 
судочинстві пропонується вважати, щзо поняття «вручення повідомлення про підозру» охоплює низку прочесуальних дій, які поступово мають бути виконані слідчим або прокурором, а саме: 1) виклик особи відповідно до вимог статей 133, 135-143 КПК; 2) установлення особи, якій повинно бути вручене повідомлення про підозру; 3) усне оголошення ій повідомлення про підозру у вчиненні конкретного кримінального правопорушення, роз'яснення суті підозри, вручення пам'ятки, відібрання в особи розписки про виконання зазначених дій слідчим або прокурором; 4) повідомлення особі про ї̈ процесуальні права і обов'язки в статусі підозрюваного, передбачені ст. 42 КПК, надання можливостей щуодо їх реалізацї; роз'яснення прав по суті (у тому числі на прохання підозрюваногост. 276 КПК), відібрання в особи відповідної розписки; 5) фактична передача письмового повідомлення про підозру особі; 6) відібрання в особи розписки про те, щзо їи вручене письмове повідомлення про підозру, із зазначенням часу та дати виконання ияєї дї слідчим або прокурором.

Повідомлення про підозру згідно з процедурою, послідовність якої закріплена в прочесуальному законі, є гарантією забезпечення права особи на інформачію щзодо здійснення стосовно неї кримінального переслідування як елементу верховенства права.

Проведений аналіз не вичерпує всіх проблемних аспектів реалізації принципу верховенства права у кримінальному провадженні, і відповідні питання мають стати предметом подальших наукових досліджень.

1. Козюбра М. Верховенство права: українські реалії та перспективи. Право України. 2010. № 3. С. 6-18.

2. Кочура А. В. Принцип Верховенства права як базовий принцип кримінального процесу. Форум права. 2010. № 4. С. 516-521.

3. Погребняк С. П. Основоположні принципи права (змістовна характеристика): монографія. Харків, 2008. 240 с.

4. Shcherbak Irina. Universality recognized international principles of criminal production and thtir implementation in the Ukrainian legislation. Scientific letters of Academic Society of Michal Baludansky. Volume 3, № 5. 2015. P. 100-103.

5. Кримінальний процесуальний кодекс України: Науково-практичний коментар : у 2 т. Т. 1 / О. М. Бандурка, Є. М. Блажівський, Є. П. Бурдоль та ін.; за заг. ред. В.Я. Тація, В. П. Пшонки, А. В. Портнова. Харків, 2012. 768 с.

6. Кримінальний процесуальний кодекс України: Закон України від 13 квітня 2012 р. № 4651-VI. Офіиійний веб-портал Верховної Ради України. URL: https://zakon.rada.gov.ua/ laws/show/4651-17 (дата звернення 01.08.2019 р.).

7. Понамаренко Д. Деякі питання повідомлення про підозру. ЛІГА. Блоги. 2017. URL: http://blog.liga. net/user/ponomarenko/article/28193.aspх (дата звернення 01.08.2019р.).

8. Шкелебей В. А. Способи та порядок вручення письмового повідомлення про підозру. Вісник кримінального судочинства. 2017. № 4. С. 110-114.

9. Судді Великої Палати Верховного Суду висловилися стосовно порядку повідомлення про підозру спецсуб'єктам. Судебно-юридическая газета. URL: https://sud.ua/ru/news/publica- 
tion/130522-suddi-vp-vs-vislovilis-stosovno-poryadku-povidomlennya-pro-pidozru-spetssubyektam (дата звернення 10.08.2019р.).

10. Про судоустрій і статус суддів: Закон України від 2 червня 2016 р. № 1402-VIII. Biдомості Верховної Ради України. 2016. № 31. Ст. 545. (Із змінами).

11. Рішення Апеляційного суду Полтавської області від 6 вересня 2016 р. у справі № 538/1807/15-к. Єдиний державний реєстр судових рімень. URL: http://www.reyestr.court. gov.ua/Review/61163287 (дата звернення 01.08.2019 р.).

12. Ухвала Донецького апеляційного суду від 15 березня 2019 р. у справі № 263/11808/18. Єдиний державний реєстр судових рімень. URL: http://www.reyestr.court.gov.ua/Review/ 80554339 (дата звернення 01.08.2019 р.).

13. Рішення Європейського суду з прав людини у справі «Беєлер проти Італії». Комюніке Секретаря Суду від 5 січня 2000 p. URL: https://ips.ligazakon.net/document/view/SO2462 (дата звернення 15.08.2019 р.).

14. Смирнов А. В., Калиновский К. Б. Уголовный процесс: учебник / под общ. ред. А. В. Смирнова. 4-е изд., перераб. и доп. М.: КНОРУС, 2008. 704 с.

15. Фараон О. Вручення повідомлення про підозру. Національний юридичний журнал: теорія і практика. MAI. 2014. С. 114-118. URL: http://www.jurnaluljuridic.in.ua/archive/ 2014/2/22.pdf (дата звернення 21.08.2019 р.). 